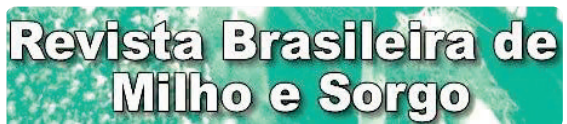

Brazilian Journal of Maize and Sorghum

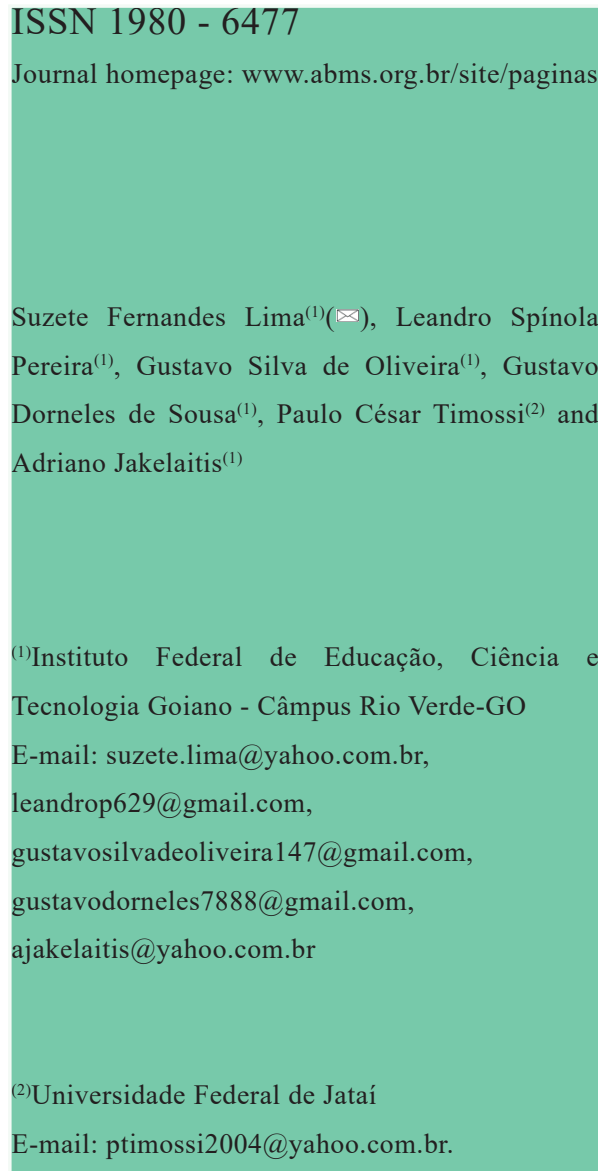

$\bowtie$ Corresponding author

How to cite

LIMA, S. F.; PEREIRA, L. S.; OLIVEIRA, G. S. SOUSA, G. D.; TIMOSSI, P. C.; JAKELAITIS, A. Maize and Urochloa spp. intercropping managed with or without glyphosate underdoses. Revista Brasileira de Milho e Sorgo, v. 19, e1121, 2020.

\section{MAIZE AND Urochloa spp. INTERCROPPING MANAGED WITH OR WITHOUT GLYPHOSATE UNDERDOSES}

\begin{abstract}
Evaluation was carried out for the interrelation between maize and Urochloa brizantha cv. Marandu and Urochloa ruziziensis, with and without application of glyphosate underdoses, and the effects of this management on weeds. For each forage species, an experiment was conducted in randomized block design, with subdivided plots. The main factor consisted of four cropping systems: intercropping of maize and $U$. brizantha, treated with 0,50 and $100 \mathrm{~g}$ a.e. $\mathrm{a}^{-1}$ of glyphosate, and maize monoculture; and for the intercropping of maize and $U$. ruziziensis, the doses of glyphosate applied were 25 and 50 g a.e. ha ${ }^{-1}$. The secondary factor consisted of five evaluation periods, with dry mass of maize and forage plants being measured on the day when the herbicide was applied, 15 days after the application, at full tasseling of maize, in hard farinaceous grain stage, and at maize harvest. Weed density and dry mass were also evaluated. The intercropping system reduced the density and dry mass production of the weed community, without affecting the maize yield components. Glyphosate suppressed the initial growth of $U$. brizantha and $U$. ruziziensis intercropped with maize, at the dose of 100 and 50 g a.e. ha ${ }^{-1}$, respectively, without compromising straw (residues) formation.
\end{abstract}

Keywords: Urochloa brizantha, Urochloa ruziziensis, weeds, no-tillage system.

\section{CONSÓRCIO ENTRE MILHO E Urochloa spp. MANEJADO OU NÃO COM SUBDOSES DE GLYPHOSATE}

Resumo - Avaliou-se a inter-relação entre o milho e Urochloa brizantha cv. Marandu e Urochloa ruziziensis, manejadas ou não com subdoses de glyphosate, e os efeitos deste manejo sobre as plantas daninhas. Para cada forrageira foi conduzido um ensaio, em delineamento de blocos casualizados, em parcelas subdivididas. O fator principal foi formado por quatro sistemas de cultivo: consórcio entre milho e $U$. brizantha tratados com 0,50 e $100 \mathrm{~g}$ e.a. ha ${ }^{-1}$ de glyphosate e monocultivo de milho. Para o consórcio entre $U$. ruziziensis e o milho, as doses de glyphosate usadas foram 25 e $50 \mathrm{~g}$ e.a. ha ${ }^{-1}$. O fator secundário foi estabelecido por cinco períodos de avaliação. Foram mensuradas a massa seca das plantas de milho e das forrageiras no dia da aplicação do herbicida, aos 15 dias após aplicação, no pleno pendoamento do milho, na fase de grão farináceo duro e na colheita do milho. Foram avaliadas também a densidade e a massa seca de plantas daninhas. O consórcio reduziu a densidade e a produção de massa seca da comunidade infestante, sem interferir nos componentes de produção do milho. O glyphosate suprimiu o crescimento inicial da U. brizantha e U. ruziziensis em consórcio com o milho, na dose de 100 e 50 g e.a. ha ${ }^{-1}$, respectivamente, sem comprometer a formação de palhada.

Palavras-chave: Urochloa brizantha, Urochloa ruziziensis, plantas daninhas, sistema plantio direto. 
Currently, the integrated crop management is regarded as one of the best practices for the sustainability of agricultural systems in the Cerrado biome region (Borghi et al., 2013) and, among the options associated with this practice, the intercropping of maize and forage species has stood out. Species of the genus Urochloa are the most used in these intercropping systems, as they present higher tolerance to adverse conditions such as water deficit (Pacheco et al., 2008). Therefore, they are used in the systems targeting both the formation of pastures and residues (straw) for no-tillage system (Machado \& Assis, 2010).

In integrated production systems, the simultaneous growth and development of the intercropped species may result in interspecific competition, which reduces the growth and development of the species and, consequently, can diminish the yield potential of grain crops. The occurrence of peaks of demand for resources from the environment at different times, by the intercropped species, softens the competition and enables the intercropping of maize and Urochloa (Pariz et al., 2011; Silva et al., 2015). Therefore, the success of intercropping systems depends on the knowledge regarding factors that affect the growth and development of the intercropped species.

Among the agronomic practices, the use of herbicide underdoses is an alternative to suppress the initial growth of the forage species (Ceccon et al., 2010; Dan et al., 2011; Grigolli et al., 2017) by delaying their growth, with their establishment in the area being possible after they recover from the injury suffered. With the adoption of genetically modified crops that are glyphosate-tolerant, this herbicide emerges as an option for the management of forage species in intercropping with maize that is genetically modified for tolerance to glyphosate (Roundup Ready $\left.^{\circledR}-\mathrm{RR}\right)$, targeting the suppression of the initial growth of the forage species.

In this context, the objective of this research was to investigate the interrelation between the cultivation of maize and the forage species Urochloa brizantha cv. Marandu and Urochloa ruziziensis, managed with glyphosate underdoses, as well as the effects of such management on the weed population dynamics.

\section{Material and Methods}

The research was carried out in the agricultural year of 2017/2018, in an experimental area of the Federal University of Goiás, Jataí Campus, GO. The soil of the experimental area is classified as dystroferric Red Latosol with clay texture (Santos et al., 2013). The climate in the region is Aw type, according to the Köppen classification, with two well-defined seasons: wet summer and dry winter. Climate data relative to the research period are shown in Figure 1.

The area presents land-use history of soybean-maize crop rotation for at least three years. Before the experiment was established, the soil analysis showed the following results: $\mathrm{pH} 5.4$ (SMP); Ca $2.30 \mathrm{cmol}_{\mathrm{c}} \mathrm{dm}^{-3} ; \mathrm{Mg} 0.87$ 


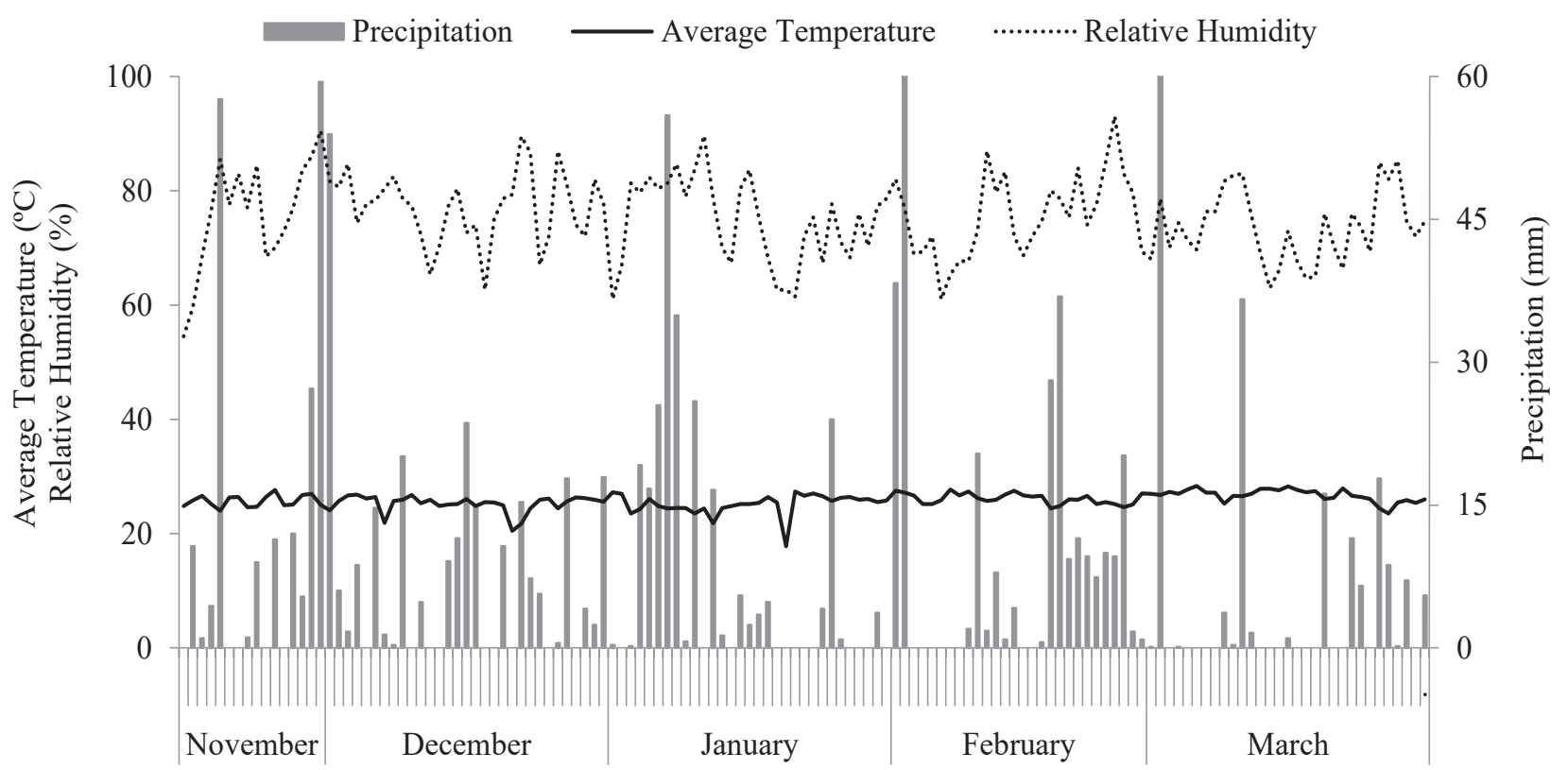

Figure 1. Average temperature $\left({ }^{\circ} \mathrm{C}\right)$, relative humidity $(\%)$ and total daily precipitation $(\mathrm{mm})$ throughout the research period (Intituto Nacional de Meteorologia, 2017, 2018).

$\mathrm{cmol}_{\mathrm{c}} \mathrm{dm}^{-3} ; \mathrm{Al}^{3+} 0.15 \mathrm{cmol}_{\mathrm{c}} \mathrm{dm}^{-3} ; \mathrm{H}+\mathrm{Al} 6.01$ $\mathrm{cmol}_{\mathrm{c}} \mathrm{dm}^{-3}$; CEC $9.55 \mathrm{cmol}_{\mathrm{c}} \mathrm{dm}^{-3}$; P (Melich)

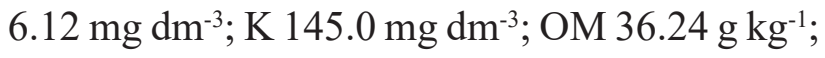
clay $67.4 \%$; silt $11.1 \%$; and sand $21.5 \%$.

An experiment was conducted for each of the forage species in intercropping with 2A401 maize hybrid (Dow AgroSciences), genetically modified for tolerance to glyphosate herbicide. The randomized block design was used, in an arrangement of subdivided plots $(4 \times 5)$, with four replications.

In experiment 1 , intercropping of maize with $U$. brizantha cv. Marandu, the main treatments consisted of four cropping systems: maize monoculture; intercropping with no application of glyphosate; intercropping treated with glyphosate underdose of $50 \mathrm{~g}$ a.e. ha ${ }^{-1}$; and intercropping treated with glyphosate underdose of $100 \mathrm{~g}$ a.e. ha ${ }^{-1}$.

In experiment 2, intercropping of maize with $U$.ruziziensis, the main treatments consisted of four cropping systems: maize monoculture; intercropping with no application of glyphosate; intercropping treated with glyphosate underdose of $25 \mathrm{~g}$ a.e. $\mathrm{ha}^{-1}$; and intercropping treated with glyphosate underdose of $50 \mathrm{~g}$ a.e. $\mathrm{ha}^{-1}$.

In both experiments, the secondary treatments consisted of five evaluation periods: the day when the treatments were applied (22 days after sowing-DAS); 15 days after treatment 
application (37 DAS); in maize flowering stage; in hard farinaceous grain stage; and at maize harvest.

Each experimental plot was composed of 12 maize rows, spaced $0.45 \mathrm{~m}$ apart, with $6 \mathrm{~m}$ length, in a total area of $32.4 \mathrm{~m}^{2}$. The outer rows (first and last), in addition to $1.0 \mathrm{~m}$ at row ends, were considered as border.

Fifteen days before the intercropping species were sown, chemical desiccation was carried out in the area, with application of glyphosate at the dose of $1200 \mathrm{~g}$ a.e. ha ${ }^{-1}$. Sowing was done on $11 / 20 / 2017$, when forage seeds were manually distributed (broadcast seeding) over the soil surface, with adoption of 400 points of crop value (CV) per ha-1 ${ }^{-1}$ Afterwards, seeds were incorporated into the soil with the use of a leveling disc harrow with closed angle. Subsequently, maize seeds were sown in rows spaced $0.45 \mathrm{~m}$ apart, with a population of 70.000 plants ha-1.

On $12 / 12 / 2017$, that is, 22 DAS, the glyphosate underdose treatments were applied, with the use of a customized $\mathrm{CO}_{2}$ pressurized sprayer coupled to a $5 \mathrm{~m}$ bar with ten TT11002 nozzles, spaced $0.50 \mathrm{~m}$ apart and positioned at a height of $0.50 \mathrm{~m}$ in relation to the plant surface, with volume of $100 \mathrm{~L} \mathrm{ha}^{-1}$ of spray solution. Spraying was done in the morning period between 11 and 11:30 am, with air temperature of $35^{\circ} \mathrm{C}$, soil temperature of $28.2{ }^{\circ} \mathrm{C}$, relative humidity of $72 \%$, cloud cover of $4 \%$, and wind speed of $1.4 \mathrm{~m} \mathrm{~s}^{-1}$. Maize plants were in the growth stage between V5 and V6. On that same day, $1000 \mathrm{~g}$ a.i. ha $^{-1}$ of atrazine were applied in all plots, in both experiments, for control of eudicotyledon species. In the maize monocultures, $480 \mathrm{~g}$ a.e. ha $^{-1}$ of glyphosate were applied.

In order to determine the dry mass of maize plants and forage species, sampling was performed on five occasions: the day when treatments were applied (22 DAS), 15 days after the application (37 DAS), in maize flowering stage (65 DAS), in hard farinaceous grain stage (100 DAS), and at maize harvest (130 DAS). In each of those evaluation periods, two maize plants were harvested per plot, while the Brachiaria species were harvested in a $0.5 \mathrm{~m}^{2}$ area. After harvesting, the plants were taken to the laboratory, where the parts were separated. The Brachiaria species were separated into stems + sheaths and leaf blade; while maize plants were separated into stems + sheaths, leaf blade, tassel and ear. For dry mass calculation, the separated plant parts were submitted to drying process in forced air circulation oven at $60^{\circ} \mathrm{C}$, until reaching constant mass.

In the same periods mentioned above, weed populations were evaluated. In each plot, an area of $0.5 \mathrm{~m}^{2}$ was sampled, where the weeds were counted, cut low to the ground and placed inside paper bags for subsequent drying in forced air circulation oven at $60^{\circ} \mathrm{C}$, until reaching constant mass. After that, the dry mass was assessed.

The results were submitted to analysis of variance, F-test $(p<0.05)$ and, when significant, the means were compared by Tukey's test $(p<0.05)$, for the main treatments, and regression 
analysis as a function of the evaluation periods. The regression equation models followed the methodology used by Jakelaitis et al. (2006).

Maize was harvested on $03 / 30 / 2018$, with subsequent evaluation of yield components, final plant stand, ear insertion height, number of ears per plant, grain yield and 1000-grain weight. Ears were manually harvested in 3 rows of $2 \mathrm{~m}$ length in each plot. From that sample, 8 ears were removed to determine the number of kernel rows per ear, number of kernels per row, ear length and ear diameter. Afterwards, the material was threshed and weighed, with the grain moisture corrected to $13 \%$. The results for yield and its components were submitted to analysis of variance and the difference between the means was compared by Tukey's test at 5\% significance.

\section{Results and Discussion}

With regard to leaf, stem and total dry mass production of maize and Urochloa plants, in both experiments, the interaction was significant between crop systems and evaluation periods (Table 1). Up to 22 DAS, when the treatments were applied, there was no significant difference as to the dry mass production of maize and Urochloa, in both experiments (Tables $2 \& 3$ ), which indicates uniform plant growth. In the following periods, there was reduction in the dry mass production of Urochloa brizantha leaves, where underdose of glyphosate was applied. As to stem and total dry mass, the reduction started 65 DAS (Figure 2 ), which demonstrates that the leaf production was affected first by the harmful effects of the herbicide. The lowest dry mass production of $U$. brizantha was observed with the use of 100 g a.e. ha ${ }^{-1}$ of glyphosate, with the herbicide having affected its growth. On the other hand, in the areas where no herbicide was applied, the forage species presented better growth, thus resulting in larger dry mass production.

The dry mass production of $U$. brizantha cv. Marandu was low until 65 DAS (Figure 2). As from 100 DAS, when the end of maize crop cycle starts, a greater increase of dry mass was observed, which may be related to the higher light incidence through the maize canopy, reaching approximately $200 \mathrm{~g} \mathrm{~m}^{-2}$ in the maize harvest period. These data corroborate the results obtained by Portes et al. (2000) and Mariani et al. (2012), who found a total dry mass production of Urochloa around $2.300 \mathrm{~kg}$ $\mathrm{ha}^{-1}$ in the maize harvest period. Lima et al. (2014), when researching the establishment and growth of cover crops in second harvest season, identified small accumulation of $U$. ruziziensis phytomass until 45 days after sowing. After that period, the forage species presented a phase of quick dry mass increment, which was followed by a production stability period, thus corroborating the results found. The Brachiaria species, when submitted to shading conditions, present slow growth as they have $\mathrm{C}_{4}$ metabolism of $\mathrm{CO}_{2}$ fixation (Portes et al., 2000).

$U$. ruziziensis presented dry mass production with linear growth during the entire development cycle of maize crop, with lower 
Table 1. F values and coefficients of variation (CV\%) applied to the means for leaf (LDM), stem (SDM) and total (TDM) dry mass of maize and Urochloa brizantha cv. Marandu (Experiment 1) and Urochloa ruziziensis (Experiment 2), as a function of crop systems (CS) and evaluation periods

\begin{tabular}{lllllcc}
\hline \multirow{3}{*}{ Treatments } & \multicolumn{3}{c}{ Maize } & \multicolumn{3}{c}{ Urochloa } \\
\cline { 2 - 6 } & LDM & SDM & TDM & LDM & SDM & TDM \\
\cline { 2 - 6 } & \multicolumn{3}{c}{ g per plant } & & $\mathrm{g} \mathrm{m}^{-2}$ \\
\hline
\end{tabular}

Experiment 1 - Intercropping of maize and Urochloa brizantha cv. Marandu

\begin{tabular}{lcccccc}
\hline CS & $2.9^{\text {ns }}$ & $19.3^{* *}$ & $3.1^{\text {ns }}$ & $431.2^{* *}$ & $145.3^{* *}$ & $205.8^{* *}$ \\
Periods & $516.1^{* *}$ & $285.3^{* *}$ & $824.0^{* *}$ & $1085.4^{* *}$ & $363.7^{* *}$ & $564.1^{* *}$ \\
CS x Period & $4.9^{* *}$ & $3.9^{* *}$ & $5.9^{* *}$ & $85.7^{* *}$ & $38.5^{* *}$ & $52.9^{* *}$ \\
\hline CV (CS) (\%) & 11.8 & 9.2 & 13.5 & 9.3 & 19.5 & 15.2 \\
CV (Periods) (\%) & 10.4 & 17.5 & 12.2 & 11.9 & 21.3 & 16.9 \\
\hline
\end{tabular}

Experiment 2 - Intercropping of maize and Urochloa ruziziensis

\begin{tabular}{lrrrccc}
\hline CS & $5.0^{* *}$ & $4.7^{*}$ & $1.3^{\text {ns }}$ & $19.2^{* *}$ & $298.0^{* *}$ & $118.2^{* *}$ \\
Periods & $430.5^{* *}$ & $470.5^{* *}$ & $675.4^{* *}$ & $423.9^{* *}$ & $363.6^{* *}$ & $464.7^{* *}$ \\
CS x Period & $5.3^{* *}$ & $2.2^{*}$ & $5.5^{* *}$ & $8.2^{* *}$ & $15.9^{* *}$ & $16.1^{* *}$ \\
\hline CV (CS) (\%) & 11.9 & 17.4 & 14.4 & 18.8 & 6.7 & 9.9 \\
CV (Periods) (\%) & 12.1 & 14.2 & 14.2 & 16.2 & 19.1 & 16.5 \\
\hline
\end{tabular}

ns (not significant); ${ }^{*}$ and $* *$ (significant at $5 \%$ and at $1 \%$ of probability, respectively).

Table 2. Leaf, stem and total dry mass of maize and Urochloa brizantha, regression equations and correlation coefficients $\left(\mathrm{R}^{2}\right)$ for the crop systems (CS): maize monoculture (MM), intercropping with no application of glyphosate $(\mathrm{CNG})$, intercropping treated with glyphosate at the dose of $50 \mathrm{~g}$ a.e. $\mathrm{ha}^{-1}$ (C50), and intercropping treated with glyphosate at the dose of $100 \mathrm{~g}$ a.e. $\mathrm{ha}^{-1}(\mathrm{C} 100)$, as a function of periods

\begin{tabular}{lccccc}
\hline \multirow{2}{*}{ CS } & \multicolumn{5}{c}{ Periods - Days After Sowing } \\
\cline { 2 - 5 } & 22 & 37 & 65 & 100 & 130 \\
\hline \multicolumn{5}{c}{ Leaf dry mass - maize } \\
\hline MM & $2.3 \mathrm{a}^{1}$ & $22.7 \mathrm{~b}$ & $33.8 \mathrm{ab}$ & $45.2 \mathrm{a}$ & $20.7 \mathrm{~b}$ \\
CNG & $2.4 \mathrm{a}$ & $24.5 \mathrm{ab}$ & $36.1 \mathrm{a}$ & $38.0 \mathrm{~b}$ & $20.7 \mathrm{~b}$ \\
C50 & $2.7 \mathrm{a}$ & $28.8 \mathrm{a}$ & $30.2 \mathrm{~b}$ & $44.7 \mathrm{a}$ & $22.9 \mathrm{~b}$
\end{tabular}




\begin{tabular}{|c|c|c|c|c|c|}
\hline $\mathrm{C} 100$ & $2.5 \mathrm{a}$ & $23.5 \mathrm{~b}$ & $37.2 \mathrm{a}$ & $43.3 \mathrm{a}$ & $28.5 \mathrm{a}$ \\
\hline \multicolumn{6}{|c|}{ Stem dry mass - maize } \\
\hline MM & $1.2 \mathrm{a}$ & $13.7 \mathrm{a}$ & $58.1 \mathrm{a}$ & $63.7 \mathrm{a}$ & $57.7 \mathrm{~b}$ \\
\hline $\mathrm{CNG}$ & $1.2 \mathrm{a}$ & $17.0 \mathrm{a}$ & $54.4 \mathrm{a}$ & $52.3 \mathrm{a}$ & $54.1 \mathrm{~b}$ \\
\hline $\mathrm{C} 50$ & $1.3 \mathrm{a}$ & $19.2 \mathrm{a}$ & $56.2 \mathrm{a}$ & $59.9 \mathrm{a}$ & $75.5 \mathrm{a}$ \\
\hline $\mathrm{C} 100$ & $1.2 \mathrm{a}$ & $14.2 \mathrm{a}$ & $55.4 \mathrm{a}$ & $63.4 \mathrm{a}$ & $85.2 \mathrm{a}$ \\
\hline \multicolumn{6}{|c|}{ Total dry mass - maize } \\
\hline MM & $3.5 \mathrm{a}$ & $36.4 \mathrm{a}$ & $127.0 \mathrm{a}$ & $306.1 \mathrm{a}$ & $249.8 \mathrm{~b}$ \\
\hline $\mathrm{CNG}$ & $3.5 \mathrm{a}$ & $41.5 \mathrm{a}$ & $129.3 \mathrm{a}$ & $260.9 \mathrm{~b}$ & $239.6 \mathrm{~b}$ \\
\hline $\mathrm{C} 50$ & $4.0 \mathrm{a}$ & $48.0 \mathrm{a}$ & $128.3 \mathrm{a}$ & $294.6 \mathrm{ab}$ & $245.0 \mathrm{~b}$ \\
\hline $\mathrm{C} 100$ & $3.7 \mathrm{a}$ & $37.7 \mathrm{a}$ & $136.9 \mathrm{a}$ & $265.9 \mathrm{~b}$ & $324.8 \mathrm{a}$ \\
\hline \multicolumn{6}{|c|}{ Leaf dry mass - Urochloa brizantha cv. Marandu } \\
\hline $\mathrm{CNG}$ & $0.3 \mathrm{a}$ & $12.5 \mathrm{a}$ & $18.8 \mathrm{a}$ & $71.0 \mathrm{a}$ & $124.3 \mathrm{a}$ \\
\hline $\mathrm{C} 50$ & $0.9 \mathrm{a}$ & $11.0 \mathrm{ab}$ & $11.9 \mathrm{~b}$ & $60.0 \mathrm{~b}$ & $108.5 \mathrm{~b}$ \\
\hline $\mathrm{C} 100$ & $0.2 \mathrm{a}$ & $5.0 \mathrm{~b}$ & $8.2 \mathrm{~b}$ & $34.6 \mathrm{c}$ & $39.3 \mathrm{c}$ \\
\hline \multicolumn{6}{|c|}{ Stem dry mass - Urochloa brizantha cv. Marandu } \\
\hline $\mathrm{CNG}$ & $0.1 \mathrm{a}$ & $9.5 \mathrm{a}$ & $21.6 \mathrm{a}$ & $110.3 \mathrm{a}$ & $143.8 \mathrm{a}$ \\
\hline $\mathrm{C} 50$ & $0.4 \mathrm{a}$ & $6.9 \mathrm{a}$ & $11.7 \mathrm{ab}$ & $71.2 \mathrm{~b}$ & $129.8 \mathrm{a}$ \\
\hline $\mathrm{C} 100$ & $0.1 \mathrm{a}$ & $3.0 \mathrm{a}$ & $7.1 \mathrm{~b}$ & $36.1 \mathrm{c}$ & $36.8 \mathrm{~b}$ \\
\hline \multicolumn{6}{|c|}{ Total dry mass - Urochloa brizantha cv. Marandu } \\
\hline CNG & $0.5 \mathrm{a}$ & $22.0 \mathrm{a}$ & $41.0 \mathrm{a}$ & $190.9 \mathrm{a}$ & $277.6 \mathrm{a}$ \\
\hline $\mathrm{C} 50$ & $1.3 \mathrm{a}$ & $17.9 \mathrm{a}$ & $23.9 \mathrm{ab}$ & $135.5 \mathrm{~b}$ & $248.7 b$ \\
\hline $\mathrm{C} 100$ & $0.3 \mathrm{a}$ & $8.0 \mathrm{a}$ & $15.6 \mathrm{~b}$ & $72.1 \mathrm{c}$ & $77.9 \mathrm{c}$ \\
\hline
\end{tabular}

${ }^{1}$ Means followed by the same letters do not differ from one another, according to Tukey's test at $\mathrm{p}<0.05 ;{ }^{2}$ Significant according to F-test at $\mathrm{p}<0.05$

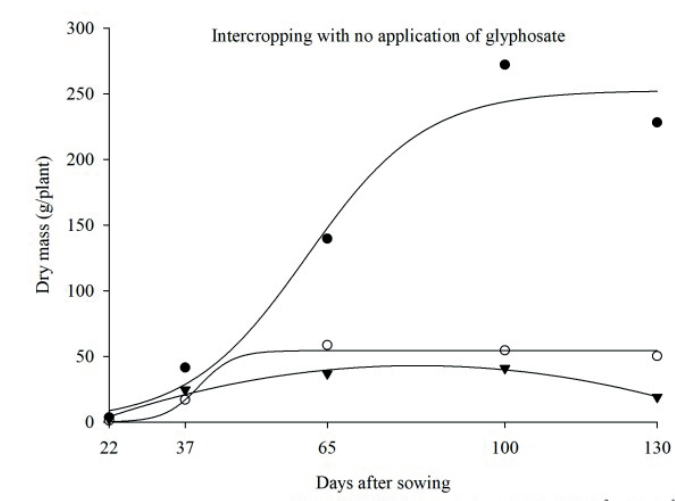

A1
Total dry mas $f(x)=278,91 /\left(1+\exp \left(-(x-62,57) / 9,04 R^{2}=90,07\right.\right.$ Stem dry mass $f(x)=71,95 /\left(1+\exp \left(-(x-48,97) / 8,06 R^{2}=99,96^{\circ}\right.\right.$

- Leaf dry mass $f(x)=-34,23+1,90 x-0,011 x^{2} R^{2}=96,40^{*}$

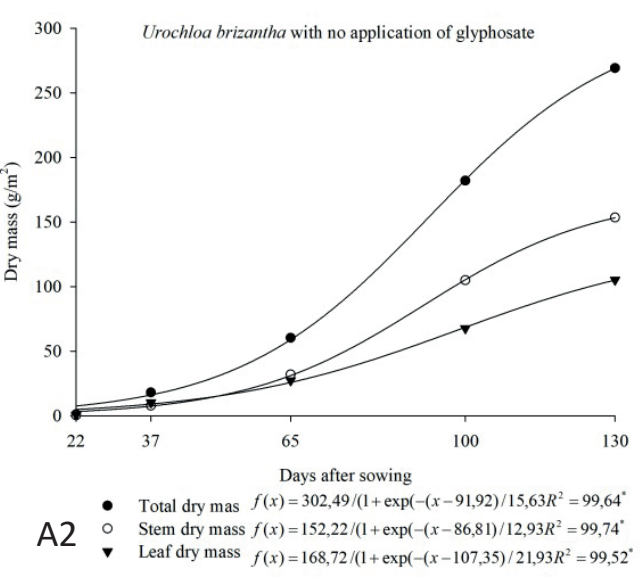

Revista Brasileira de Milho e Sorgo, v.19, e1121, 2020 DOI: https://doi.org/10.18512/rbms2020v19e1121 


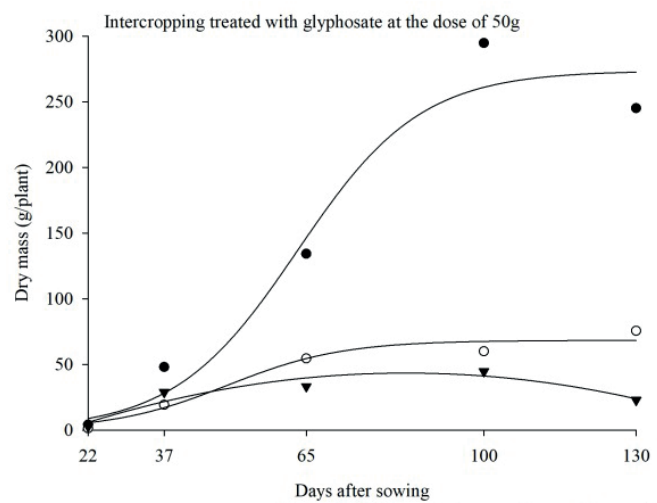

B1

- Total dry mas $f(x)=273,48 /\left(1+\exp \left(-(x-64,18) / 11,93 R^{2}=95,76^{\circ}\right.\right.$

- Stem dry mass $f(x)=68,01 /\left(1+\exp \left(-(x-48,32) / 10,55 R^{2}=96,52^{\circ}\right.\right.$

- Leaf dry mass $f(x)=-21,52+1,44 x-0,008 x^{2} R^{2}=83,68^{*}$

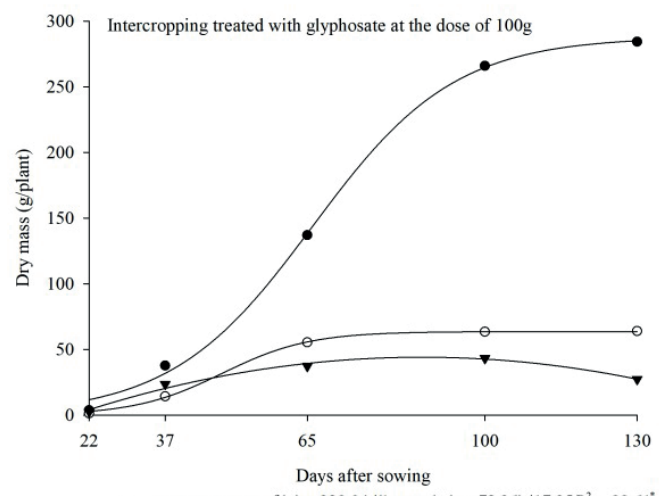

C1

- Total dry mas $f(x)=329,04 /\left(1+\exp \left(-(x-72,36) / 17,35 R^{2}=99,61^{\circ}\right.\right.$

- Stem dry mass $f(x)=75,75 /\left(1+\exp \left(-(x-54,57) / 11,79 R^{2}=95,50^{\circ}\right.\right.$

- Leaf dry mass $f(x)=-24,75+1,51 x-0,008 x^{2} R^{2}=98,04^{\circ}$

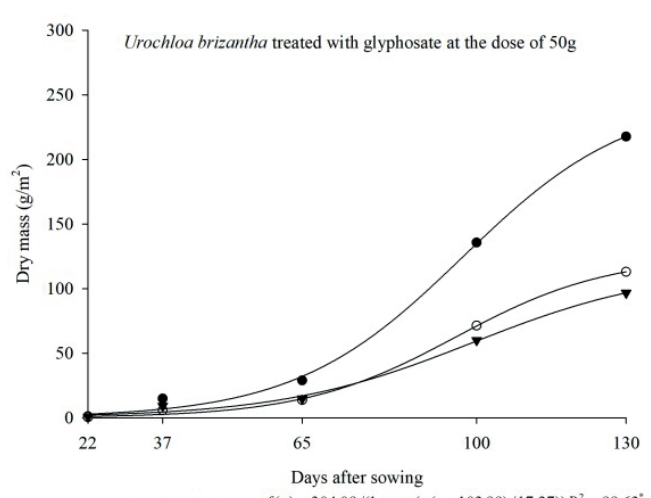

B2 - Total dry mas $f(x)=304,09 /(1+\exp (-(x-103,99) / 17,27)) R^{2}=99,63^{\circ}$ Stem dry mass $f(x)=152,22 /(1+\exp (-(x-102,15) / 15,81)) R^{2}=99,82^{\circ}$

V Leaf dry mass $f(x)=142,24 /(1+\exp (-(x-106,70) / 19,80)) R^{2}=99,25^{\circ}$

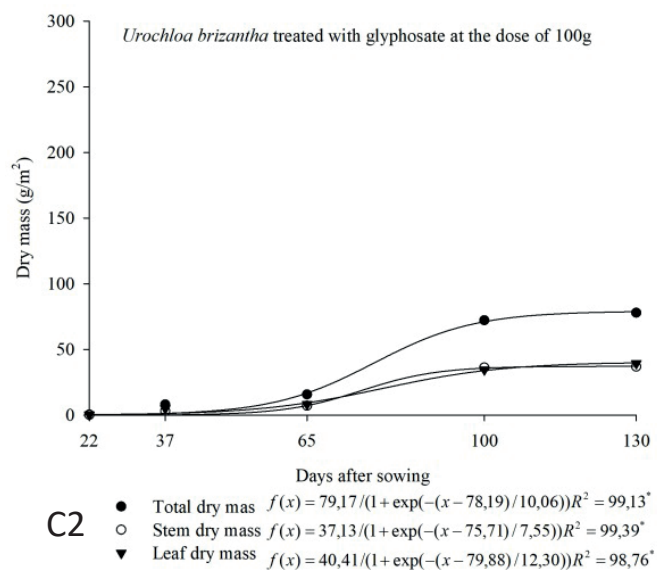

D

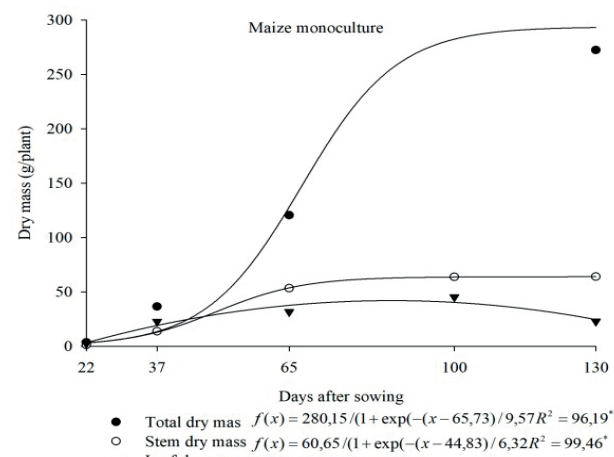

Stem dry mass $f(x)=60,65 /\left(1+\exp \left(-(x-44,83) / 6,32 R^{2}=99,46^{\circ}\right.\right.$
Leaf dry mass $f(x)=-28,29+1,64 x-0,009 x^{2} R^{2}=95,31^{\circ}$

Figure 2. Leaf, stem and total dry mass of maize and Urochloa brizantha, regression equations and correlation coefficients $\left(\mathrm{R}^{2}\right)$ for the crop systems: intercropping with no application of glyphosate (A1 \& A2), intercropping treated with glyphosate at the dose of 50 g a.e. ha ${ }^{-1}$ (B1 \& B2), intercropping treated with glyphosate at the dose of $100 \mathrm{~g}^{\text {a.e. }} \mathrm{ha}^{-1}(\mathrm{C} 1 \& \mathrm{C} 2)$ and maize monoculture (D), as a function of periods 
yield in areas where glyphosate herbicide was used. The largest dry mass production of $U$. ruziziensis occurred in the intercropping system with no application of glyphosate underdose (Table $3 \&$ Figure 3). The lower dry mass production confirms the interference of the herbicide effect with the development of the forage species. According to Silva et al. (2005), the use of herbicide selective for the grain-producing crop, in the intercropping system, will favor that crop and, if there are phytotoxic effects on the forage species, its dry mass yield will be reduced. Herbicide selectivity for forage grasses depends on the species, the development stage, the herbicide molecule, and the intercropping purpose (Martins et al., 2007). For Ceccon et al. (2010), the later the application of herbicides in the intercropping system, the lower will be the phytotoxic effects on the Brachiaria.

In both experiments, there was small accumulation of maize dry mass until 37 DAS, with a following period of rapid dry mass increment until 100 DAS (Tables $2 \& 3$, Figure $2 \& 3$ ). These dry mass accumulation phases of maize plant parts were similar to those reported by Oliveira et al. (2013). The plant dry mass accumulation, in most of the cases, encompasses three phases: in the first phase, there is slow growth, with accumulation of about $2 \%$ of its total dry mass of aerial part; in the second phase, the aerial part presents fast growth, with accumulation of about $91 \%$ of dry mass; and the third phase is characterized as maturation stage, with accumulation of about $7 \%$ of its dry mass of aerial part (Gava et al., 2010).

The dry mass production of maize leaves begins to decrease after 100 DAS (Figure $2 \& 3$ ), indicating the end of the cycle, which coincides with the period of larger dry mass accumulation of the Brachiaria, which may be related to the higher light incidence due to senescence and subsequent fall of maize plant leaves. In both experiments, the dry mass accumulation in the stem was larger than in the leaves. Larger dry mass accumulation of leaves and stems was verified up to flowering (65 DAS). After that period, there was stability in leaf and stem production until the hard farinaceous grain period (100 DAS). Subsequently, leaf dry mass started to decrease as a result of the beginning of its senescence. As from 50 DAS, the greater total dry mass contribution is associated with ear formation, which presents increasing dry mass values as of its emergence up to the end of the cycle.

With regard to density and dry mass production of weeds, no significant interactions were observed between crop systems and evaluation periods(Table4)forbothexperiments. The dry mass of the weed community was greater in the maize monoculture, indicating that the forage species contributed to the suppression of weeds, since the use of chemical control alone resulted in larger dry mass production of weeds, which demonstrates the importance of adopting the integrated management system. According to Gimenes et al. (2011), weed control can be favored by the cultivation of forage species intercropped with maize, with the forage grass having influence on the weed distribution and 
Table 3. Leaf, stem and total dry mass of maize and Urochloa ruziziensis, regression equations and correlation coefficients $\left(\mathrm{R}^{2}\right)$ for the crop systems $(\mathrm{CS})$ : maize monoculture $(\mathrm{MM})$, intercropping with no application of glyphosate (CNG), intercropping treated with glyphosate at the dose of $25 \mathrm{~g}$ a.e. $\mathrm{ha}^{-1}(\mathrm{C} 25)$, and intercropping treated with glyphosate at the dose of $50 \mathrm{~g}$ a.e. $\mathrm{ha}^{-1}(\mathrm{C} 50)$, as a function of periods

\begin{tabular}{|c|c|c|c|c|c|}
\hline \multirow{2}{*}{$\mathrm{CS}$} & \multicolumn{5}{|c|}{ Periods - Days After Sowing } \\
\hline & 22 & 37 & 65 & 100 & 130 \\
\hline & \multicolumn{5}{|c|}{ Leaf dry mass - maize } \\
\hline MM & $2.6 \mathrm{a}^{1}$ & $21.4 \mathrm{a}$ & $29.4 \mathrm{~b}$ & $38.6 \mathrm{~b}$ & $26.7 \mathrm{ab}$ \\
\hline $\mathrm{CNG}$ & $2.6 \mathrm{a}$ & $23.0 \mathrm{a}$ & $38.3 \mathrm{a}$ & $50.6 \mathrm{a}$ & $20.8 \mathrm{c}$ \\
\hline $\mathrm{C} 25$ & $2.6 \mathrm{a}$ & $20.9 \mathrm{a}$ & $32.8 \mathrm{ab}$ & $46.5 \mathrm{a}$ & $28.2 \mathrm{a}$ \\
\hline \multirow[t]{2}{*}{$\mathrm{C} 50$} & $2.2 \mathrm{a}$ & $22.3 \mathrm{a}$ & $28.5 \mathrm{~b}$ & $48.1 \mathrm{a}$ & $21.5 \mathrm{bc}$ \\
\hline & \multicolumn{5}{|c|}{ Stem dry mass - maize } \\
\hline $\mathrm{MM}$ & $1.4 \mathrm{a}$ & $13.0 \mathrm{a}$ & $46.9 \mathrm{~b}$ & $57.6 \mathrm{~b}$ & $67.9 \mathrm{ab}$ \\
\hline $\mathrm{CNG}$ & $1.3 \mathrm{a}$ & $13.7 \mathrm{a}$ & $63.1 \mathrm{a}$ & $72.0 \mathrm{a}$ & $72.0 \mathrm{a}$ \\
\hline $\mathrm{C} 25$ & $1.3 \mathrm{a}$ & $12.2 \mathrm{a}$ & $51.5 \mathrm{~b}$ & $68.2 \mathrm{ab}$ & $62.3 \mathrm{ab}$ \\
\hline \multirow[t]{2}{*}{$\mathrm{C} 50$} & $1.1 \mathrm{a}$ & $13.7 \mathrm{a}$ & $46.8 \mathrm{~b}$ & $64.6 \mathrm{ab}$ & $60.5 \mathrm{~b}$ \\
\hline & \multicolumn{5}{|c|}{ Total dry mass - maize } \\
\hline $\mathrm{MM}$ & $4.0 \mathrm{a}$ & $34.4 \mathrm{a}$ & $117.9 \mathrm{ab}$ & $264.8 \mathrm{~b}$ & $296.8 \mathrm{a}$ \\
\hline $\mathrm{CNG}$ & $3.8 \mathrm{a}$ & $36.7 \mathrm{a}$ & $149.8 \mathrm{a}$ & $335.1 \mathrm{a}$ & $222.7 \mathrm{~b}$ \\
\hline $\mathrm{C} 25$ & $3.9 \mathrm{a}$ & $33.1 \mathrm{a}$ & $125.6 \mathrm{ab}$ & $318.1 \mathrm{a}$ & $293.0 \mathrm{a}$ \\
\hline \multirow[t]{2}{*}{$\mathrm{C} 50$} & $3.2 \mathrm{a}$ & $36.0 \mathrm{a}$ & $107.7 \mathrm{~b}$ & $320.9 \mathrm{a}$ & $248.8 \mathrm{~b}$ \\
\hline & \multicolumn{5}{|c|}{ Leaf dry mass - Urochloa ruziziensis } \\
\hline $\mathrm{CNG}$ & $0.5 \mathrm{a}$ & $20.5 \mathrm{a}$ & $22.7 \mathrm{a}$ & $38.0 \mathrm{~b}$ & $75.0 \mathrm{a}$ \\
\hline $\mathrm{C} 25$ & $0.1 \mathrm{a}$ & $8.1 \mathrm{~b}$ & $14.0 \mathrm{~b}$ & $47.6 \mathrm{a}$ & $61.2 \mathrm{~b}$ \\
\hline \multirow[t]{2}{*}{$\mathrm{C} 50$} & $0.4 \mathrm{a}$ & $7.8 \mathrm{~b}$ & $14.9 \mathrm{~b}$ & $26.2 \mathrm{c}$ & $58.8 \mathrm{~b}$ \\
\hline & \multicolumn{5}{|c|}{ Stem dry mass - Urochloa ruziziensis } \\
\hline $\mathrm{CNG}$ & $0.3 \mathrm{a}$ & $17.3 \mathrm{a}$ & $30.3 \mathrm{a}$ & $59.6 \mathrm{~b}$ & $127.8 \mathrm{a}$ \\
\hline $\mathrm{C} 25$ & $0.1 \mathrm{a}$ & $7.5 \mathrm{a}$ & $18.3 \mathrm{~b}$ & $73.6 \mathrm{a}$ & $74.9 \mathrm{~b}$ \\
\hline \multirow[t]{2}{*}{$\mathrm{C} 50$} & $0.3 \mathrm{a}$ & $6.6 \mathrm{a}$ & $15.3 \mathrm{~b}$ & $41.0 \mathrm{c}$ & $78.7 \mathrm{~b}$ \\
\hline & \multicolumn{5}{|c|}{ Total dry mass - Urochloa ruziziensis } \\
\hline $\mathrm{CNG}$ & $0.8 \mathrm{a}$ & $37.8 \mathrm{a}$ & $55.7 \mathrm{a}$ & $103.1 \mathrm{~b}$ & $220.1 \mathrm{a}$ \\
\hline $\mathrm{C} 25$ & $0.2 \mathrm{a}$ & $15.6 \mathrm{~b}$ & $32.6 \mathrm{~b}$ & $128.2 \mathrm{a}$ & $142.4 \mathrm{~b}$ \\
\hline $\mathrm{C} 50$ & $0.7 \mathrm{a}$ & $14.5 \mathrm{~b}$ & $30.5 \mathrm{~b}$ & $69.6 \mathrm{c}$ & $143.6 \mathrm{~b}$ \\
\hline
\end{tabular}

${ }^{1}$ Means followed by the same letters do not differ from one another, according to Tukey's test at $\mathrm{p}<0.05 ;{ }^{2}$ Significant according to F-test at $\mathrm{p}<0.05$ 


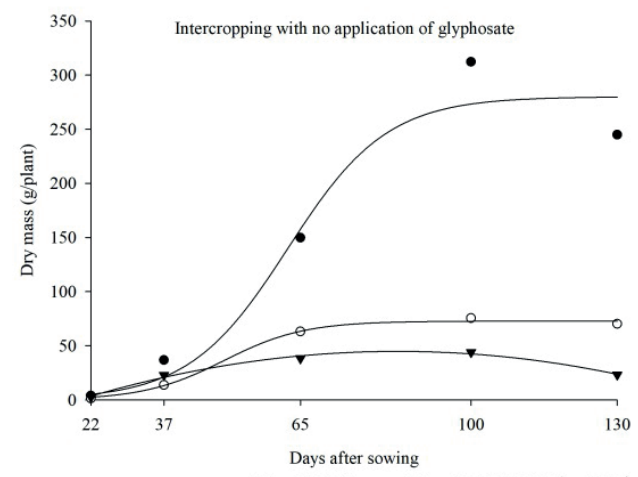

A1

- $\quad$ Total dry mass $f(x)=278,91 /(1+\exp (-(x-62,57) / 9,04)) R^{2}=90,07^{\circ}$ Stem dry mass $f(x)=71,95 /(1+\exp (-(x-48,97) / 8,06)) R^{2}=99,96^{\circ}$ Leaf dry mass $f(x)=-34,23+1,90 x-0,011 x^{2} R^{2}=96,40^{*}$

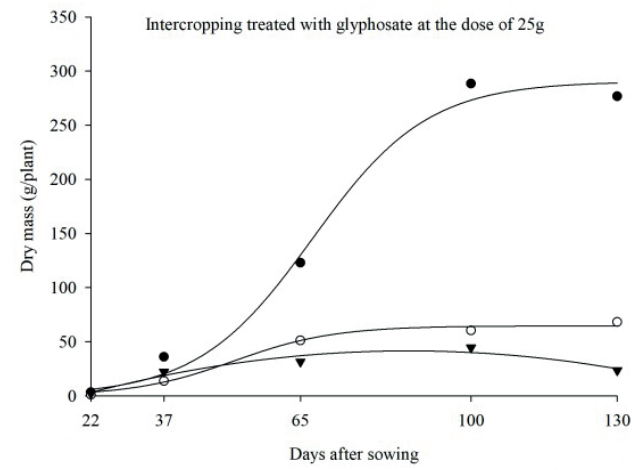

B1 Total dry mass $f(x)=310,25 /(1+\exp (-(x-67,99) / 9,82)) R^{2}=98,68^{\circ}$ - Stem dry mass $f(x)=65,29 /(1+\exp (-(x-51,93) / 9,60)) R^{2}=99,38^{\circ}$

- Leaf dry mass $f(x)=-25,75+1,49 x-0,008 x^{2} R^{2}=96,27^{\circ}$

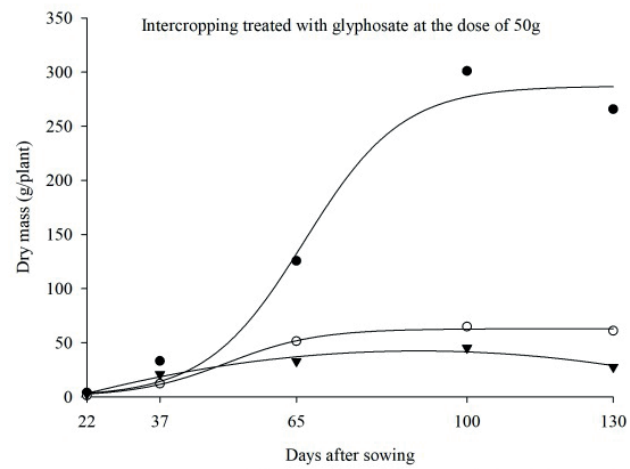

C1

- Total dry mass $f(x)=284,92 /(1+\exp (-(x-67,74) / 5,72)) R^{2}=94,85$

- Stem dry mass $f(x)=62,73 /(1+\exp (-(x-52,52) / 10,88)) R^{2}=99,34$

- Leaf dry mass $f(x)=-27,32+1,55 x-0,008 x^{2} R^{2}=86,89^{\circ}$

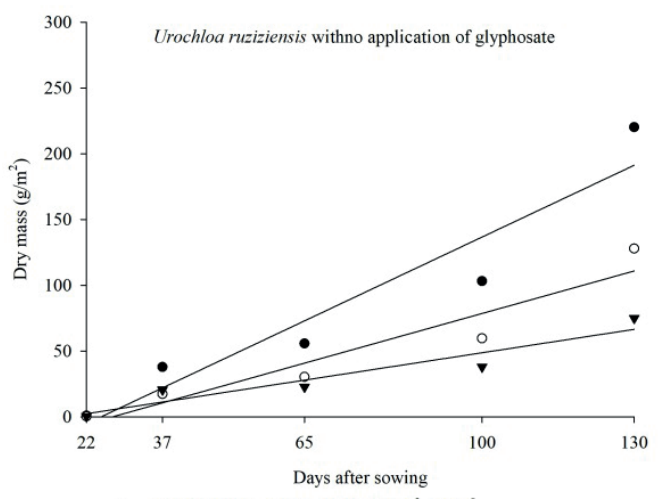

A2

- Total dry mas $f(x)=-45,37+1,82 x R^{2}=91,16$

- Stem dry mass $f(x)=-29,28+1,07 x R^{2}=91,71$

V Leaf dry mass $f(x)=-10,71+0,59 x R^{2}=90,19^{\circ}$

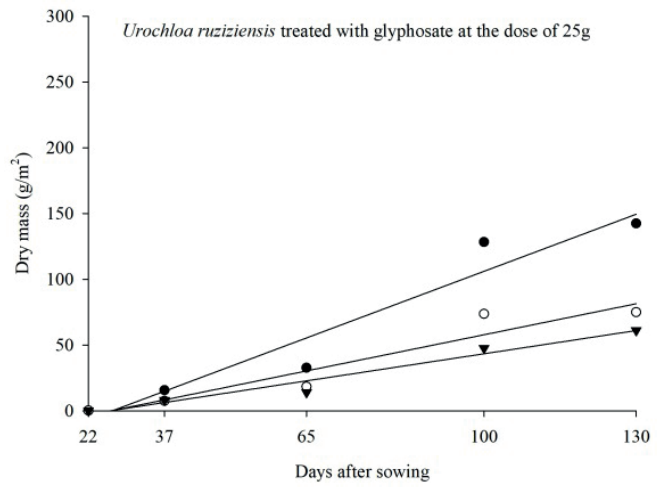

B2

- Total dry mas $f(x)=-38,62+1,44 x R^{2}=93,73^{\circ}$

- Stem dry mass $f(x)=-20,75+0,78 \times R^{2}=91,72^{\circ}$

- Leaf dry mass $f(x)=-15,43+0,58 x R^{2}=96,33^{\circ}$

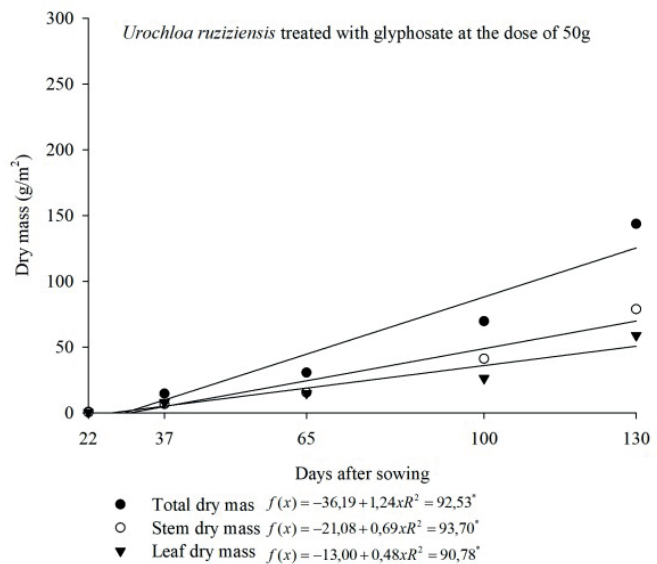




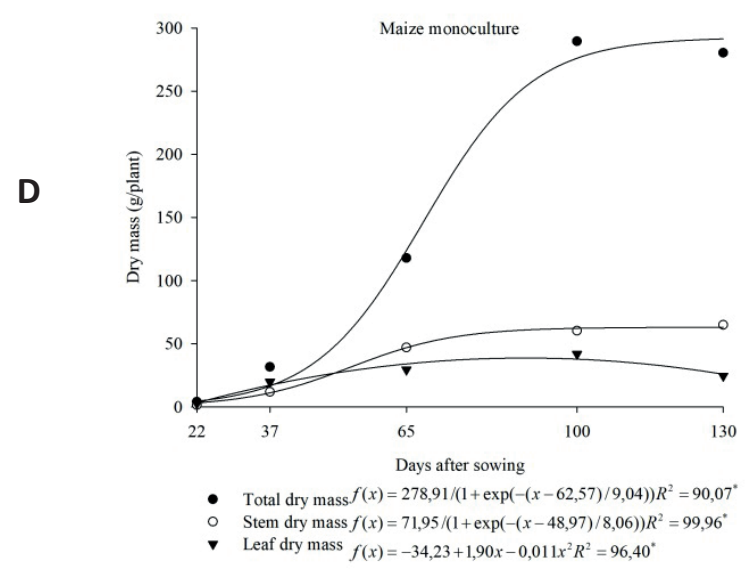

Figure 3. Leaf, stem and total dry mass of maize and Urochloa ruziziensis, regression equations and correlation coefficients $\left(\mathrm{R}^{2}\right)$ for the crop systems: intercropping with no application of glyphosate (A1 \& A2), intercropping treated with glyphosate at the dose of 25 g a.e. ha ${ }^{-1}$ (B1 \& B2), intercropping treated with glyphosate at the dose of $50 \mathrm{~g}$ a.e. $\mathrm{ha}^{-1}(\mathrm{C} 1 \& \mathrm{C} 2)$, and maize monoculture (D), as a function of periods

infestation in the area.

Weed density was reduced until 100 DAS. After that period, there was an increase in the number of weeds (Table 4). The use of chemical control, associated with the development of Brachiaria and maize plants, reduced weed density. In the period when the dry mass of maize leaves begins to decrease, that is, after 100 DAS, a weed emergence flow occurred, increasing its density, without resulting in increment of dry mass production. This weed germination flow is associated with the increase of light incidence on the soil surface, as well as spaces not yet occupied by the forage species.

In experiment 1, intercropping of maize and $U$. brizantha $\mathrm{cv}$. Marandu, higher values for 1000-grain weight and ear length were found in the intercropping systems. The lack of herbicide and the application of $50 \mathrm{~g}$ a.e. $\mathrm{ha}^{-1}$ of glyphosate did not differ from the maize monoculture (Table 5), which may be related to the larger dry mass production of weeds in maize monoculture (Table 4) and to the higher growth of the forage species with no herbicide application and with the use of $50 \mathrm{~g}$ a.e. ha ${ }^{-1}$ of glyphosate (Table 2).

With regard to the other yield components, stand density, ear insertion height, number of ears per plant, number of kernel rows per ear, number of kernels per row, ear diameter and grain yield, no statistical difference was identified, leading to the conclusion that there was no interference of cv. Marandu with the productive characteristics of maize, that is, 
Table 4. $\mathrm{F}$ values and coefficients of variation (CV\%) applied to the means for density (DS) and dry mass (DM) of weeds in the experiments of intercropping of maize with Urochloa brizantha cv. Marandu (Experiment 1) and intercropping of maize with Urochloa ruziziensis (Experiment 2), for the crop systems (CS): maize monoculture (MM), intercropping with no application of glyphosate $(\mathrm{CNG})$, intercropping treated with glyphosate at the dose of $50 \mathrm{~g}$ a.e. $\mathrm{ha}^{-1}(\mathrm{C} 50)$, and intercropping treated with glyphosate at the dose of $100 \mathrm{~g}$ a.e. $\mathrm{ha}^{-1}(\mathrm{C} 100)$, as a function of evaluation periods

\begin{tabular}{|c|c|c|c|c|}
\hline \multirow{3}{*}{ Sources of Variance } & \multicolumn{2}{|c|}{ Experiment 1} & \multicolumn{2}{|c|}{ Experiment 2} \\
\hline & DS & $\mathrm{DM}$ & DS & $\mathrm{DM}$ \\
\hline & plants $\mathrm{m}^{-2}$ & $\mathrm{~g} \mathrm{~m}^{-2}$ & plants $\mathrm{m}^{-2}$ & $\mathrm{~g} \mathrm{~m}^{-2}$ \\
\hline $\mathrm{CS}$ & $15.2^{* *}$ & $45.9^{* *}$ & $7.9^{* *}$ & $32.0^{* *}$ \\
\hline Periods & $10.4^{* *}$ & $2.7^{\mathrm{ns}}$ & $10.2^{* *}$ & $1.2^{\mathrm{ns}}$ \\
\hline CS x Period & $1.4^{\mathrm{ns}}$ & $2.1^{\mathrm{ns}}$ & $0.7^{\mathrm{ns}}$ & $0.4^{\mathrm{ns}}$ \\
\hline $\mathrm{CV}(\mathrm{CS})(\%)$ & 56.5 & 66.2 & 73.0 & 75.1 \\
\hline CV (Periods) $(\%)$ & 42.4 & 58.4 & 67.8 & 85.5 \\
\hline \multicolumn{5}{|l|}{ Crop System } \\
\hline $\mathrm{MM}$ & $55.00 \mathrm{a}$ & $99.67 \mathrm{a}$ & $54.13 \mathrm{a}$ & $105.54 \mathrm{a}$ \\
\hline $\mathrm{CNG}$ & $17.13 b$ & $27.25 \mathrm{~b}$ & $20.50 \mathrm{~b}$ & $19.91 \mathrm{~b}$ \\
\hline C50 & $21.00 \mathrm{~b}$ & $8.42 \mathrm{~b}$ & $21.63 \mathrm{~b}$ & $13.23 \mathrm{~b}$ \\
\hline C100 & $30.38 \mathrm{~b}$ & $14.91 \mathrm{~b}$ & $26.50 \mathrm{~b}$ & $24.69 \mathrm{~b}$ \\
\hline \multicolumn{5}{|c|}{ Periods - Days After Sowing } \\
\hline 37 & 39.00 & 41.25 & 47.88 & 42.19 \\
\hline 65 & 38.88 & 48.27 & 41.75 & 53.09 \\
\hline 100 & 16.75 & 27.93 & 14.37 & 37.60 \\
\hline 130 & 28.88 & 32.73 & 18.75 & 30.47 \\
\hline Regression & n.a. & & n.a. & \\
\hline
\end{tabular}


Table 5. F values and coefficients of variation (CV\%) applied to the means for plant stand (S), ear insertion height $(\mathrm{EIH})$ in cm, number of ears per plant (NEP), number of kernel rows per ear (NKRE), number of kernels per row (NKR), ear length (EL) in cm, ear diameter (ED) in cm, 1000-grain weight (TGW) in g, and grain yield (GY) in $\mathrm{kg} \mathrm{ha}^{-1}$, for experiment 1 (Intercropping of maize and Urochloa brizantha $\mathrm{cv}$. Marandu) and for experiment 2 (Intercropping of maize and Urochloa ruziziensis)

\begin{tabular}{|c|c|c|c|c|c|c|c|c|c|}
\hline \multirow{2}{*}{$\begin{array}{l}\text { Source of } \\
\text { Variance }\end{array}$} & $\mathrm{S}$ & $\mathrm{EIH}$ & \multirow{2}{*}{ NEP } & \multirow{2}{*}{ NKRE } & \multirow{2}{*}{ NKR } & EL & ED & TWG & GY \\
\hline & n. $m^{-1}$ & $\mathrm{~cm}$ & & & & $\mathrm{~cm}$ & $\mathrm{~cm}$ & $\mathrm{~g}$ & $\mathrm{~kg} \mathrm{ha}^{-1}$ \\
\hline
\end{tabular}

Experiment 1: Intercropping of maize and Urochloa brizantha cv. Marandu

\begin{tabular}{lccccccccc}
\hline CS & $0.4^{\mathrm{ns}}$ & $1.0^{\mathrm{ns}}$ & $0.5^{\mathrm{ns}}$ & $1.5^{\mathrm{ns}}$ & $1.8^{\mathrm{ns}}$ & $5.7^{*}$ & $1.5^{\mathrm{ns}}$ & $6.5^{*}$ & $0.2^{\mathrm{ns}}$ \\
$\mathrm{CV}(\%)$ & 2.8 & 5.1 & 6.0 & 3.4 & 5.0 & 5.0 & 5.6 & 2.3 & 15.1 \\
\hline $\mathrm{MM}$ & 3.0 & 104.9 & 0.93 & 17.3 & 31.0 & $14.0 \mathrm{~b}$ & 5.0 & $319.0 \mathrm{~b}$ & 9.766 .2 \\
$\mathrm{CNG}$ & 3.0 & 103.5 & 0.97 & 17.3 & 30.3 & $15.1 \mathrm{ab}$ & 5.3 & $328.9 \mathrm{ab}$ & 8.981 .3 \\
$\mathrm{C} 50$ & 3.0 & 104.7 & 0.95 & 17.0 & 31.8 & $15.2 \mathrm{ab}$ & 5.2 & $327.13 \mathrm{ab}$ & 9.575 .1 \\
$\mathrm{C} 100$ & 3.0 & 109.8 & 0.95 & 16.5 & 30.3 & $16.3 \mathrm{a}$ & 4.4 & $342.2 \mathrm{a}$ & 9.425 .1 \\
\hline
\end{tabular}

Experiment 2: Intercropping of maize and Urochloa ruziziensis

\begin{tabular}{lccccccccc}
\hline $\mathrm{CS}$ & $1.3^{\mathrm{ns}}$ & $2.4^{\mathrm{ns}}$ & $3.7^{\mathrm{ns}}$ & $2.6^{\mathrm{ns}}$ & $0.3^{\mathrm{ns}}$ & $0.8^{\mathrm{ns}}$ & $1.4^{\mathrm{ns}}$ & $1.6^{\mathrm{ns}}$ & $0.3^{\mathrm{ns}}$ \\
$\mathrm{CV}(\%)$ & 5.8 & 4.4 & 4.9 & 3.5 & 7.0 & 4.5 & 3.1 & 5.4 & 9.9 \\
\hline $\mathrm{MM}$ & 3.0 & 100.4 & 0.9 & 16.3 & 32.0 & 14.7 & 5.1 & 328.0 & 9.285 .2 \\
$\mathrm{CNG}$ & 2.9 & 107.1 & 0.9 & 17.3 & 31.5 & 15.0 & 5.2 & 324.5 & 9.162 .9 \\
$\mathrm{C} 50$ & 3.0 & 108.1 & 0.9 & 16.3 & 33.0 & 14.9 & 5.1 & 340.4 & 9.745 .5 \\
$\mathrm{C} 100$ & 2.8 & 103.4 & 1.0 & 16.5 & 32.0 & 15.4 & 5.3 & 349.6 & 9.562 .9 \\
\hline
\end{tabular}

ns (not significant); * and ** (significant at $5 \%$ and at $1 \%$ of probability, respectively); ${ }^{1}$ Means followed by the same letters in the columns do not differ from one another, according to Tukey's test at $\mathrm{p}<0.05$

there was no competition between the plants capable of reducing grain yield (Table 5). The competition between the species forming the plant community only happens when the competing species' demand for resources from the environment exceeds the capacity of the environment to supply those resources or when one of the competing species prevents the other from accessing the resource (Gimenes et al., 2011).

In experiment 2, intercropping of maize and U. ruziziensis, there was no difference regarding 
maize yield components (Table 5). Therefore, it can be stated that, considering the $0.45 \mathrm{~m}$ spacing and the edaphoclimatic conditions of this research, $U$. ruziziensis did not interfere with yield components of maize crop. It is worth mentioning that the application of glyphosate to reduce the growth rate of the forage species, though not affecting maize yield components, may be an alternative to reduce dry mass of the forage species in the harvest period, which would facilitate the grain harvesting operation. These results corroborate those found by Crusciol et al. (2010) and Chioderoli et al. (2012), which demonstrated that intercropping of maize and Urochloa did not produce negative effect on maize yield.

\section{Conclusions}

Glyphosate suppresses the initial growth of $U$. brizantha cv. Marandu and $U$. ruziziensis in intercropping with maize, at the dose of 100 and $50 \mathrm{~g}$ a.e. $\mathrm{ha}^{-1}$, respectively. The highest increment in dry mass of $U$. brizantha $\mathrm{cv}$. Marandu and $U$. ruziziensis occurred after the farinaceous grain stage of maize. Intercropping of maize with $U$. brizantha $\mathrm{cv}$. Marandu and U. ruziziensis reduces density and dry mass production of the weed community. The cultivation of $U$. brizantha $\mathrm{cv}$. Marandu and $U$. ruziziensis in intercropping with maize, with and without application of glyphosate underdose, in the $0.45 \mathrm{~m}$ spacing, does not interfere with maize yield components.

\section{Acknowledgments}

To the Coordination for the Improvement of Higher Education Personnel - Brazil (CAPES) - Finance Code 001; and to the Federal Institute of Education, Science and Technology of Goiás (IF Goiano) for the financial support.

\section{References}

BORGHI, E.; CRUSCIOL, C. A. C.; MATEUS, G. P.; NASCENTE, A. S.; MARTINS, P. O. Intercropping time of corn and palisadegrass or guineagrass affecting grain yield and forage production. Crop Science, v. 53, n. 2, p. 629636, 2013.

CECCON, G.; MATOSO, A. O.; NETO, A. L. N.; PALOMBO, L. Uso de herbicidas no consórcio de milho safrinha com Brachiaria ruziziensis. Planta Daninha, v. 28, n. 2, p. 359-364, 2010. DOI: 10.1590/S0100-83582010000200015.

CHIODEROLI, C. A.; MELlO, L. M. M.; HOLANDA, H. V.; FURLANI, C. E. A.; GRIGOLLI, P. J.; SILVA, J. O. R.; CESARIN, A. L. Consórcio de Urochloas com milho em sistema plantio direto. Ciência Rural, v. 42, n. 10, p. 1804-1810, 2012. DOI: 10.1590/S010384782012005000073.

CRUSCIOL, C. A. C.; SORATTO, R. P.; BORGHI, E.; MATEUS, G. P. Benefits of 
integrating crops and tropical pastures as systems of production. Better Crops, v. 94, n. 2, p. 14-16, 2010.

DAN, H. A.; BARROSO, A. L. L.; DAN, L. G. M.; PROCÓPIO, S. O.; OLIVEIRA JÚNIOR, R. S.; CONSTANTIN, J.; FELDKIRCHER, C. Supressão imposta pelo mesotrione a Brachiaria brizantha em sistema de integração lavoura-pecuária. Planta Daninha, v. 29, n. 4, p. 861-867, 2011. DOI: 10.1590/S010083582011000400016.

GAVA, G. J. C.; OLIVEIRA, M. W.; SILVA, M. A.; JERÔNIMO, E. M.; CRUZ, J. C. S.; TRIVELIN, P. C. O. Produção de fitomassa e acúmulo de nitrogênio em milho cultivado com diferentes doses de ${ }^{15} \mathrm{~N}$-urea. Semina: Ciências Agrárias, v. 31, n. 4, p. 851-862, 2010.

DOI: 10.5433/1679-0359.2010v31n4p851.

GIMENES, M. J.; PRADO, E. P.; POGETTO, M. H. F. A. D.; COSTA, S. Í. A. Interferência da Brachiaria decumbens Stapf. sobre plantas daninhas em sistema de consórcio com o milho. Revista Caatinga, v. 24, n. 3, p. 215-220, 2011.

GRIGOLLI, J. F. J.; GITTI, D. C.; LOURENÇÃO, A. L. F. Controle de plantas de soja e supressão do capim em milho consorciado com Brachiaria ruziziensis. Arquivos do Instituto Biológico, v. 84, e0592015, 2017. DOI: 10.1590/18081657000592015.
INMET. Instituto Nacional de Meteorologia. Clima. Brasília, DF, 2017. Available in: <http:// www.inmet.gov.br>. Accessed in: 15 March, 2017.

INMET. Instituto Nacional de Meteorologia. Clima. Brasília, DF, 2018. Available in: <http:// www.inmet.gov.br>. Accessed in: 15 March, 2018.

JAKELAITIS, A.; SILVA, A. A.; SILVA, A. F.; SILVA, L. L.; FERREIRA, L. R.; VIVIAN, R. Efeitos de herbicidas no controle de plantas daninhas, crescimento e produção de milho e Brachiaria brizantha em consórcio. Pesquisa Agropecuária Tropical, v. 36, n. 1, p. 53-60, 2006.

LIMA, S. F.; TIMOSSI, P. C.; ALMEIDA, D. P.; SILVA, U. R. Fitossociologia de plantas daninhas em convivência com plantas de cobertura. Revista Caatinga, v. 27, n. 2, p. 37-47, 2014.

MACHADO, L. A. Z.; ASSIS, P. G. G. Produção de palha e forragem por espécies anuais e perenes em sucessão à soja. Pesquisa Agropecuária Brasileira, v. 45, n. 4, p. 415-422, 2010.

DOI: 10.1590/S0100-204X2010000400010.

MARIANI, F.; FONTANELI, R. S.; VARGAS, L.; SANTOS, H. P.; FONTANELI, R. S. Estabelecimento de gramíneas forrageiras tropicais perenes simultaneamente com as 
culturas de milho e soja no Norte do RS. Ciência

Rural, v. 42, n. 8, p. 1471-1476, 2012.

DOI: 10.1590/S0103-84782012000800023.

MARTINS, D.; TRIGUERO, L. R. C.; DOMINGOS, V. D.; MARTINS, C. C.; MARCHI, S. R.; COSTA, N. V. Seletividade de herbicidas aplicados em pós-emergência sobre capim-braquiária. Revista Brasileira de Zootecnia, v. 36, n. 6, p. 1969-1974, 2007. DOI: 10.1590/S1516-35982007000900004.

OLIVEIRA, P.; NASCENTE, A. S.; KLUTHCOUSKI, J.; PORTES, T.A. Crescimento e produtividade de milho em função da cultura antecessora. Pesquisa Agropecuária Tropical, v. 43, n. 3, p. 239-246, 2013. DOI: 10.1590/ S1983-40632013000300005.

PACHECO, L. P.; PIRES, F. R.; MONTEIRO, F. P.; PROCÓPIO, S. O.; ASSIS, R. L.; CARMO, M. L.; PETTER, F. A. Desempenho de plantas de cobertura em sobressemeadura na cultura da soja. Pesquisa Agropecuária Brasileira, v. 43, n. 7, p. 815-823, 2008. DOI: 10.1590/S0100204X2008000700005.

PARIZ, C. M.; ANDREOTTI, M.; AZENHA, M. V.; BERGAMASCHINE, A. F.; MELLO, L. M. M.; LIMA, R. C. Produtividade de grãos de milho e massa seca de braquiárias em consórcio no sistema de integração lavoura-pecuária. Ciência Rural, v. 41, n. 5, p. 875-882, 2011.
DOI: 10.1590/S0103-84782011000500023.

PORTES, T. A.; CARVAlHO, S. I. C.; OLIVEIRA, I. P.; KLUTHCOUSKI, J. Análise do crescimento de uma cultivar de braquiária em cultivo solteiro e consorciado com cereais. Pesquisa Agropecuária Brasileira, v. 35, n. 7, p. 1349-1358, 2000. DOI: 10.1590/S0100204X2000000700009.

SANTOS, H. G. dos; JACOMINE, P. K. T.; ANJOS, L. H. C. dos; OLIVEIRA, V. A. de; LUMBRERAS, J. F.; COELHO, M. R.; ALMEIDA, J. A. de; CUNHA, T. J. F.; OLIVEIRA, J. B. de. Sistema brasileiro de classificação de solos. 3. ed. rev. e ampl. Brasília, DF: Embrapa, 2013. 353 p.

SILVA, A. C.; FERREIRA, L. R.; SILVA, A. A.; BELO, A. F.; SEDIYAMA, C. S. Caracteres morfológicos de soja e braquiária consorciadas sob subdoses de fluazifop-p-butil. Ciência Rural, v. 35, n. 2, p. 277-283, 2005. DOI: 10.1590/S0103-84782005000200005.

SILVA, D. V.; PEREIRA, G. A. M.; FREITAS, M. A. M.; SILVA, A. A.; SEDIYAMA, T.; SILVA, G. S.; FERREIRA, L. R.; CECON, P. R. Produtividade e teor de nutrientes do milho em consórcio com braquiária. Ciência Rural, v. 45, n. 8, p. 1394-1400, 2015. DOI: 10.1590/0103$8478 \mathrm{cr} 20140760$. 